The Façade and the Picture Plane

Catherine Ferguson

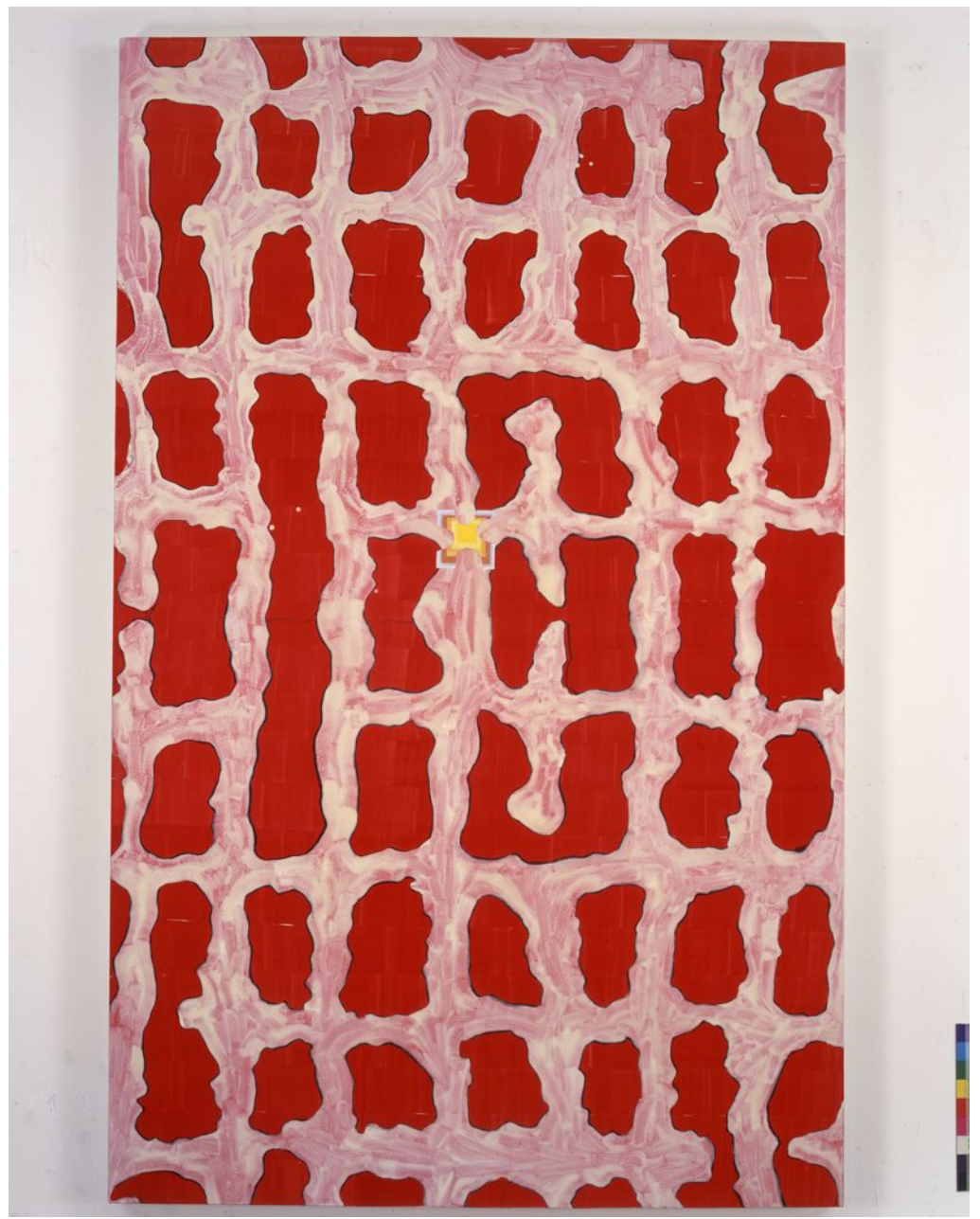

Juan Usle

La Garganta de Albers, Las Muelas de Gaudi (Albers' Throat, the Teeth of Gaudi) (2003) 
Keywords: Painting, Autopoiesis, Metaphor, Façade, Usle, Deleuze

Abstract

If, following Bois, the task of the painter is the development of a thought that is properly pictorial (Bois, 1990: 248), then this article will explore the idea of commitment as a problem for discourse: any claim about a painting's relation to its outsides being a function of what writing is capable of saying in the face of such a thought. Appropriating the biological model of autopoiesis (which sets out to analyse the genesis of a living form from its point of view rather than from the observer's), the essay analyses Usle's painting La Garganta de Albers, Las Muelas de Gaudi in order to demonstrate that its outsides are a production of its internal "organisation". This internal organisation cannot be described (from the outside) and so the article suggests the idea that the painting functions through the metaphor of the façade. Ultimately, there is no real evidence for this because the relation between writing and painting is marked by discontinuity. However, although this is a problem for the writer (who might want to control what the painting means) this methodological problem is a sign of commitment in so far as the incomprehensibility encountered in front of the painting elicits a new kind of thinking inaugurated by the work's specificity. 
Where does a painting begin? Not with an empty canvas but with the need '...to erase, to clean, to flatten, even to shred, so as to let in a breath of air from the chaos that brings us the vision.' (Deleuze and Guattari, 1994: 204)

What would a 'committed' painting practice look like, who for and who is to say? This article will discuss one painting by Juan Usle La Garganta de Albers, Las Muelas de Gaudi (Albers' Throat, the Teeth of Gaudi) (2003); henceforth referred to as G/A. This may seem a challenging task as the history of abstract painting is inseparable from various theories that have accompanied its evolution, most notably those Modernist discourses of Greenberg and Fried whose logic explicitly separated the domain of painting from any notion of content that could not be found in the immediacy of aesthetic conviction. On the other hand this choice may turn out to be an opportunity; for rather than begin with assumptions built upon so many givens that pre-exist the specificity of the work of art (e.g. that abstract painting is necessarily autonomous of any political or social concerns) writing could open itself up to the work and be educated by it; it could create a form of analysis that is not about painting but, in the words of Hubert Damisch, 'proceeds with it' [Damisch, 1995: 263]. In this case writing becomes a medium for that education and the problem of commitment in relation to painting becomes, not so much about determining a general idea about how painting can be understood as committed, but what a specific painting proposes about itself as a committed practice. 
The idea that a painting can make such a proposal is an expression of what Yve-Alain Bois termed 'Painting as Model' [Bois, 1990: 245-257]. Writing in the 1990s, in the context of debates about the death of painting and postmodernism, Bois' lengthy introduction to his collection of essays Painting as Model, makes explicit key principles of a methodology that begins with the primacy and specificity of the artwork. He cites Roland Barthes who insists that 'one does not "apply" a theory; that concepts must be forged from the object of one's inquiry or imported according to that object's specific exigency; and that the main theoretical act is to define this object, not the other way around'. [Bois, 1990: xii] Each essay in Bois' book takes the problematic nature of a specific work as its point of departure and invents or imports theoretical models, in part or whole, from other disciplines (what Bois calls a 'right-to-store up' policy) in order to strive for a 'renewed intimacy' with the work. This 'renewed intimacy' belongs properly to painting, not as if painting has a universal essence, but in the sense that each specific painting is the actualisation of thought; not the thought of the person who painted it but of thought which belongs to painting itself. Hence, if a work were seen as "committed" it would not be because of a quality or attribute identifiable in the work (which would amount to a projection of thoughts, values and ideas onto the work) but because "commitment" is a production of the work. Thus, a committed practice also re-defines that term; it is an event of commitment rather than an example of commitment. The interests of an art historian writing in the 1990s are inevitably different from those of a painter writing now. However, the primacy Bois gives to an experience of the artwork over any theoretical model is a valuable lesson for an artist whose priority is making paintings but who also knows how significant ideas are for developing a critical practice. So, despite never having seen G/A (thereby running the risk of contradicting a central tenet of Bois' 
methodology) what is more important to me is that the image has had a sustained significance for my studio practice over many years. The impetus to explore the composition of G/A in writing runs parallel to an exploration of it through painting and I am insisting on the primacy and specificity of 'the work' in assemblage with my own. In other words this is not an attempt at an 'objective' analysis. Although I have no memory of standing in front of G/A it has become a part of my imaginative life and, like a musical score which, for the musician, allows her to hear in her mind what is yet to be played, the image in the book is 'doubled' by my memories of actual paintings (including ones I have seen by Usle) and by my own history of making paintings and my aspirations for future ones.

If, in the studio, my interest in G/A is inseparable from a position inside the activity of painting, this is an investigation of the possibility of writing from that same position; from the point of view of the work itself not from the outside perspective of the one who would judge the work to be committed. And if the observer, who would write from a fixed and static position external to the work, no longer structures what is written then the same must be true for the art work which (consistent with how it feels to make paintings) can no longer be approached as a fixed and static object.

That is why those who are nothing but painters are also more than painters, because they "bring before us, in front of the fixed canvas," not the resemblance but the pure sensation "of a tortured flower, of a landscape slashed, pressed, and plowed," giving back "the water of the painting to nature". (Deleuze and Guattari, 1994: 167) 
Deleuze's reference to Artaud on Van Gogh emphasises what we already know; that painting is metamorphosis; that 'material pass[es] completely into ... sensation, into the percept or affect'. The desire to put Usle's painting to work in my own painting is not to look on it 'objectively' in terms of its supposed form, structure or meaning, but repeat the life of his painting through the production of my own. If writing can do the same then it has to discover a relation to the work that also is not 'objective', even though, within its own terms it must stand up to scrutiny. Instead of beginning with what is given, what we assume to be there, the idea of being "educated by the work" suggests that we are open to what we do not immediately recognise; to translate its 'signs':

Learning is essentially concerned with signs. Signs are the object of a temporal apprenticeship, not of an abstract knowledge. To learn is first of all to consider a substance, an object, a being as if it emitted signs to be deciphered, interpreted. (Deleuze, 2000: 4)

The sense of the work as a form of life, which emits signs that are interpreted by the text, draws on the biological theories of Maturana and Varela whose concept of "autopoiesis" was developed in order to make a logical distinction between living and non-living entities (Maturana and Varela, 1980). Their aim was to develop a method capable of analysing the genesis of that entity as a living form; that is from the point of view of the organism and not from the position of the observer who would examine the organism when fully formed. This philosophy of life resonates very closely with that of the work of Gilbert Simondon for whom 
the individual is not a form but a process of individuation; so that in order to grasp its genesis it is necessary to search for the principle of individuation which precedes it rather than taking the individual itself as the given starting point (Simondon, 1992: 297-319).

The orientation towards process orientates analysis away from judgement (of a form) towards understanding the work as process; a process of individuation which is both the production of a unity and the production of an outside. As Maturana and Varela say '...our problem is the living organisation and therefore our interest will not be in properties of components, but in processes and relation between processes realised through components' (Maturana and Varela, 1980: 75). It is the organism's network of relations or 'organisation' as a dynamic process that defines the stability of the living being and which creates a relation to the outside, but it is an outside that is paradoxically created at the same time as the individuating organism. In this respect the environment is understood to be subjective and species-specific and not the pre-given, fixed and objective environment in which Darwin's organisms compete for survival. Interestingly for the work of art as a form of life (and a "committed" practice) the logic of autopoiesis insists that the genesis of a new species is also the creation of a new form of sensing the world. Earlier writers such as the 19thC ethologist Jakob von Uexkull (Bains, 2001:137-167) also viewed environment as a species-specific Umwelt and understood the form of a living organism to develop through its 'contrapuntal' rather than causal relations with other organisms and its physical habitat. These contrapuntal relations are semiotic processes by which the organism responds, not to identities but to difference; the organism interprets its environment through 'significant sign relationships' and not as a passive object subject to a given environment and the forces of natural selection. The number of potential differences that surround the system is infinite so for difference to become 
information that can be interpreted these differences must first be selected by the recipient system. Thus, information from surroundings is conceived of as difference that makes a difference to the recipient.

This information is a sign for the organism that interprets it. What are the signs that the painting emits for writing which are different from those that are important to painting? As Bois insists, instead of applying a theory writing has the capacity to create concepts and ideas by bringing together other writings (imported in part or whole); it can find paths through ideas that unfold and translate the signs of painting. To "proceed with" painting is not to write about its cause but it is to explore what the materials and processes of writing can do through a dynamic 'contrapuntal' relation to the painting which is made of different stuff. The ideas of autopoiesis and individuation suggest certain possibilities for thinking about G/A as process not form; for thinking its virtual organisation and not its outward appearance; but the risk is that the discussion remains at a theoretical distance for that very reason. So, the idea that the work is a form of life is not specific enough. What is it about this painting that interests writing and which can be explored through concepts of understanding rather than illustrate those concepts?

The most explicit 'sign' is a reference to the work of Josef Albers, included both in the title and through a motif painted in the centre, in the upper half. The motif recognisably refers to Albers' Homage to the Square series of paintings which he began in 1950 and made during the final twenty six years of his life. Having said that it is upside down; Albers' squares gravitated towards the bottom edge not the top edge and the white border on the outside is unusual in Alber's oeuvre, which brings with it the suggestion that this may be a transcription 
of a reproduction rather than of a painting (I imagine Usle flicking through his Albers catalogue in his studio.)

Such an explicit appropriation is unusual in Usle's oeuvre whose work does refer to other artist's work but typically through suggestion and implication. This is in contrast with the prevalence of ironic quotation of a Modernist lexicon of gestures and images which was common in the 1990s and which provided the context for Bois' arguments articulated in his essays 'Painting as Model' and 'Painting: The Task of Mourning' (Bois, 1990). Usle would be aware of this but rather than following suite the Albers motif seems to have a more important role to play than as a linguistic sign for the death of painting. In other words it is not simply a part that joins with others to produce a whole; each subsumed by the 'meaning' of the painting. This is consistent with the idea that, although the autopoietic organism is a unity, it cannot be defined as this sum of its parts. The distinction Maturana and Varela make between (actual) components and structure and (virtual) organisation is crucial. As they say '...autopoietic machines are unities whose organisation is defined by a particular network of processes (relations) of production of components, the autopoietic network, not by the components themselves or their static relations.' [Maturana and Varela, 1980: 79] and furthermore '.. the organisation of a machine is independent of the properties of its components which can be any, and a given machine can be realised in many different manners by many different kinds of components...' (Maturana and Varela, 1980: 77). This means that it is necessary to determine the specificity of those components only in so far as they generate relations which define the autopoietic machine as a unity. Thus, for the Albers motif to become generative it must be thought of in its relation to another component which, although less explicit (perhaps only suggested by the title) refers to the architecture of Gaudi, 
in particular eccentric shapes that mimic external features of his buildings. Because the organisation of this work is virtual we can learn nothing from describing the way these components fit together on the surface of the painting. In fact the painting is experienced as a unity and it is worth repeating that the task is not to pull the components apart and describe relations between them (the structure of the work) but to find a way to think about the genesis of relations i.e. the process of individuation, in which the components play their part. This is a significant point because although the process of individuation, by definition, implies unity it is not the static unity of the fully formed organism, totalised and observable from a transcendental position. Writing from the position of individuation implies the unity of a living form created in time and the need for a different understanding of its components as generative.

So, if from the outside the Albers motif could be identified as an ironic sign for post-modernism, the creation of an autopoietic entity would suggest the creation of an inside through which this image is overcome; a cliché emptied of all its certainty. In other words, as a component on the inside it has a reality of its own that is not the same as it would have on the outside. For this act of transformation to happen it is as if Albers' painting ceased to become an identifiable form (e.g. as an interchangeable sign of Modernism) and became ‘information'. The writer David Scott notes that within Simondon's philosophy of individuation '...Information displaces form. Information reveals itself through the “emergence of signification”...' [Scott, 2014, p40]. Furthermore, the lesson of autopoiesis tells us that Albers' painting (as an environmental factor, a 'sign' to which G/A responds) becomes 'information' only because of G/A's in-built receptivity. This receptivity is both determined by a past evolution, genetically encoded, and simultaneously and paradoxically 
the opportunity for that past to be re-figured by what it receives. In other words this painting by Albers is both outside the (activity of) painting as a visible material object and inside the (activity of) painting as an invisible force; a genetic element hidden from view (an encoded, structuring force in the history of abstract painting).

It is as if the 'Albers painting' is split in two. On the one hand (outside G/A) it reminds us of an object of perception that can be remembered, described and written about but on the other hand, through a juxtaposition with other components (inside G/A), its own virtual organisation returns in the present sensation of the painting.

...Proust sees memory as the quite possibly infinite reservoir of what was never actually experienced, so to speak, but which returns all the same: a sort of unlived experience, if you like, which Proust is going to make the very matter of literature. (de Beistegui, 2013: 28)

This idea of 'unlived' experience, to which de Beistegui refers, is crucial because although it refers to the past it is not the past that was once experienced and now forgotten, but the memory of what remains to be lived and what's still to come in any lived experience. This suggests the possibility that with every perception or lived experience there is an accompanying unconscious 'unlived' experience; a time that doubles that which we are aware of, as he puts it 'a fold of the real' (de Beistegui, 2013: 51) and he goes on to say: 
...Proust's most radical discovery: the fact that time is always divided in two, into present and past, just as life's always divided into lived and unlived experience. And it's the latter, this unlived experience that's the concern of literature. (de Beistegui, 2013: 45)

The implication is that Albers' painting becomes information for G/A, not as image or form (the memory of perception of an identity) but as a memory of what has no form or identity. This memory of what was never lived is what was left when a perception was cut from a plenitude of sensations but which remained awaiting action and, in this sense, is a memory of feelings. In the temporal paradox of sensation, the unlived returns, not through a conscious act of remembering but through the irruption of involuntary memory. This is not to fictionalise the event of involuntary memory as that which was experienced by artist or viewer, but it is to give it a place in writing; to acknowledge the role of involuntary memory as a principle of an encounter with the work as sensation not as image. The challenge is to show how the 'unlived', which returns through involuntary memory, can be understood to become schematised in the work of art. As this cannot be done through observation and description it can only be attempted using the tools of writing to produce another space that is no more than a metaphor, perhaps, for the painting.

In this endeavour it seems appropriate to begin by using a figure that belongs to writing; the metonym. Roman Jakobson made a famous distinction between metaphor and metonymy in his essay 'Two Aspects of Language and Two Types of Aphasic Disturbances' (Jakobson, 1987: 95-114): the metonym being a figure of speech that operates through contiguity or 
context (the horizontal axis of language) and metaphor a figure of speech that operates by similarity (the vertical axis of language). Although not following Jakobson's definition fully, the argument does begin with the idea that the Albers motif operates metonymically by association with Modernism: its discourses and practices. Albers is a part of that history of painting/culture which is brought into Usle's painting through a relationship of contiguity, by association. Although what exactly we mean by Modernism is not the issue here, the image of Albers' work undoubtedly associates with utopian ideals; the essentialism and historicism of Modernism and in particular the pleasure of eyesight. But these are generalisations and the motif is quite specific; it introduces the specificity of Albers' experimentations metonymically (i.e. by concentrating all of the other paintings in the Homage to the Square series into this part) and actually; as a formal arrangement of those experimentations: the rhythm of colours as they interact with one another across the surface, the chromatic interval between colours, the weight of colours. The Albers motif sits in a position that mimics the central square of Albers' own painting (reversing the gravitational weight) embedded into the Gaudi component which draws out its specific chromatic and compositional musicality. Like a keynote the 'throat of Albers' generates tempo, tone, rhythm and interval to create the voice of the work which vibrates through the 'teeth of Gaudi'. The sense of contraction and expansion, made sensible by the quantity/quality colour relations of the Albers square, extends across the intense red surface through the positive and negative shapes made by white paint scumbled on top. The Albers square operates as a pseudo centre (evoking but not engaging with the structure of figurative composition, and its compositional hierarchy) whose role is not so much to be seen but to displace vision and move the work of the painting along; akin to the role played by the goal of the game which is to set the game in motion and sustain 
play but which has no real value itself. On the other hand, Gaudi's eccentric facades, translated onto a two dimensional surface, amplify the structure of Albers' painting by creating the warp of a colour field with the weft of the interval which weaves in and out of the saturated picture plane. It is as if, through the Gaudi component, Albers' work becomes 'dispersed' rather than reified as a completed object of art history: the fragment we call Albers (its image) both 'draws within itself ....affects that are essentially heterogeneous' (de Beistegui, 2013: 102) but at the same time it becomes many Albers ('a multiplicity of vessels') (de Beistegui, 2013: 105) a moment of dispersal that happens as a relation with another heterogeneous part. Rhythms, interval, forces are freed from the form of the pictorial surface to play on the empty façade of Usle's painting. But if the Albers motif demonstrates metonymy's horizontality across the surface then the "Gaudi façade" has a metaphoric relation to that surface only in so far as it might lend itself to or double the pictorial façade. Of course this is not to say that the picture surface represents the façade of one of Gaudi's buildings and it could be argued that it is only through the title that this connection could be made at all.

In a lengthy and complex discussion of 'the art of metaphor' in Proust's novel In Search of Lost Time de Beistegui sets out:

...to show that, from a properly poetic perspective, one I'd qualify as onto-poetic, metaphor no longer involves comparison and involves resemblance even less...metaphor will turn out to be the transposition to the poetic level of an otherwise philosophical issue, namely that of difference. The distinctiveness of metaphor lies in 
its ability to present or schematise difference: metaphor is the sensible figure of difference, its poetic schema. (de Beistegui, 2013: 76-77)

De Beistegui insists that resemblance is not the condition for bringing the two terms of the metaphor together. As he says 'Metaphor doesn't reveal shared or common qualities' ... [but]... 'discloses another level of the real...that moves beneath the fixed world of genres and species' (de Beistegui, 2013: 77). This complicates what would seem to be a reasonable assumption to make. Having said that, the idea that the relation between the Albers component as a metonym and the Gaudi component as a metaphor mimics Jakobson's structural condition of language does suggest that this would be no more than an attempt to describe the structure of Usle's painting rather than its 'organisation' - a distinction which is highly significant for Maturana and Varela . Consistent with de Beistegui's insistence on metaphor as the schematisation of difference, although sensation may begin with a degree of resemblance '...a spark that sets the flame or the lightening that joins the sky and the earth...' (de Beistegui, 2013:67) what the metaphor ties together are two series that communicate through difference not resemblance. The true metaphor is not Gaudi's façade but its operation with, its inseparability from, Albers' square. Furthermore, it makes sense to follow Bois' example (Bois, 1990: 60) and make an analogy with the concept of "arche-writing" (developed by Derrida to denote that which is prior to the hierarchisation of speech and writing) and call this proper metaphor an "arche-metaphor" because it overcomes the opposition between metaphor and metonymy (de Beistegui, 2013:93). Conventionally metaphor involves seeing the same in what is different which, de Beistegui notes, is not temporal and therefore not adequate for a discussion of the work of art as a form of life (de 
Beistegui, 2013: 76). In fact, the (arche)metaphor and the surface proper are heterogeneous terms that cannot be compared. The (arche)metaphor is not an object (or a noun) for it expresses the virtual organisation of the autopoietic organism. I have attempted to describe this as beginning with a relation or tension between two different, heterogeneous axes of the vertical metaphor (Gaudi) and horizontal metonym (Albers) but it is also this opposition that the (arch)metaphor overcomes. Thus, although the arch-metaphor is an idea that began with a description of how I might imagine those axes to work together its true nature as a metaphor can only be established according to logical argument, in thought.

So, with a perception of G/A in the present there is a metamorphosis, not because we are reminded of what resembles its image (which would actually distract our attention away from the picture surface) but because the (arche)metaphor displaces or dislocates perception; frees consciousness from the necessities of practical action (which includes comprehension) through the irruption of involuntary memory. Through the operation of the (arche)metaphor the unlived returns but it is now clear that an argument rooted in description is not adequate and so we must return to the idea that Albers and Gaudi are not form for G/A but information and it is the relation that they generate as the 'organisation' of G/A through the return of the unlived that we must grasp.

We might think of the 'unlived' in terms of Deleuze's notion of the virtual which he distinguishes from the possible as that which does not resemble the real or lived. As Daniel Smith explains,

The virtual, as Deleuze formulates it, is not subject to a process of realisation, but rather a process of actualisation, and the rules of actualisation are not resemblance 
and limitation, but rather divergence and difference - in other words, creation and novelty. (Smith, 2012:252)

Thus, the virtual 'unlived' generates what is actually lived but equally when it returns through involuntary memory it returns differently. As de Beistegui notes 'It's not the past that involuntary memories bring back to me, then, but that part of the past that hasn't yet passed. And it's not yet passed because it's never been present...' (de Beistegui, 2013: p45). At the risk of over-simplification we could think of the 'unlived' as a realm of terms/sensations that must remain unconscious because of an irresolvable difference or contradiction. At the point of conscious perception the contradiction appears to disappear but that relation of difference remains as internal to perception itself (Smith 2012:pp245-246). So for example, although in this case it is possible to identify the façade as a general aspect of (architectural) form, for 'the Gaudi façade' to become 'information' which G/A can receive it is necessary to think in terms of its 'genetic differentials'.

Hubert Damisch has argued (Vidler 2005: 209) that Modernist architecture turned buildings inside out, and diminished the importance of the façade, claiming that Modernism's orientation towards the architectural plan replaced the facade of Baroque architecture as a sign of value. Thus, we can think of a building's actual façade as generated by a relation between the differential terms "vertical, fictive façade" and "horizontal, literal plan". Likewise, the picture plane can be thought of as generated by a differential relation between a façade of depiction (absolute artifice), on the one hand, and the surface of expression (absolute truth) on the other. Significantly here, the evolution of abstract painting demonstrates an increasing emphasis on the material stuff of paint as expressivity became located on the surface of the painting rather than behind the façade of depiction. 
If the spark of resemblance connects the picture plane to Gaudi's architectural façade it is also true that the Albers motif could not work as a metaphor because it is not different - it is a painted surface, as is G/A. Thus, the (arche)metaphor reveals something shared beneath the difference of façade and picture plane. The (arche)metaphor brings together two sets of generative differential relations; oppositions whose terms are different but whose relations are shared. What in painting could be described as an opposition of the terms 'narrative of objective truth' vs 'narrative of subjective truth', in architecture this relation is repeated as 'value of the outside' vs 'value of the inside'.

The argument I am trying to make is that through the figure of the (arche)metaphor these terms return differently. It is as if Gaudi's refusal to value the plan over the facade in architecture became a sign for $\mathrm{G} / \mathrm{A}$; for an abstract painting that is at once expressive and rooted in the phenomena of the objective, visual world. It is as if the exclusion of artifice in Albers' almost scientific explorations and the extreme opticality of his paintings became a sign for $\mathrm{G} / \mathrm{A}$; for an abstract painting that acknowledges the body and the tactility of its material facture as well as the expressivity of rhythm and colour. But these signs are not symmetrical: Albers refusal of façade has become part of a larger façade; one that is allowed to return to abstract painting through the figure of Gaudi.

Of course, this return of the façade is not the return of a façade as it was ever experienced. Whereas a voluntary memory includes the perspective of the subject i.e. it is situated in relation to the subject who remembers, involuntary memory is the return of the "unlived". As 
Benjamin puts it 'only what has not been experienced explicitly and consciously, what has not happened to the subject as an experience, can become a component of the memoire involontaire'. (Benjamin, 1992:157) Without the effort of will what returns is that which was of no interest to perception in the past but remains as a pure past accompanying every present. At the moment of return the past and the present are synthesised to cancel out temporal distance.

The time that separates them is annulled and they are carried onto another level, another temporality. They converge in a sort of instantaneousness that runs parallel to the flow of time, a sort of "time outside time" that is at the same time the very essence of time, what Proust calls "time in its pure state". (de Beistegui, 2013:56)

This implies that, although the event of metamorphosis is, in principle, local to an encounter with the work and it is located in the figure of the façade, it is not experienced as a conscious idea that has an equivalent form in time and space. The significance of involuntary memory is that it marks a moment of forced memory and forced thought. As Deleuze writes 'the Idea is not the element of knowledge but that of an infinite 'learning', which is of a different nature to knowledge. What this implies is that the Idea is also an encounter with incomprehensibility, but not from lack of knowledge. As he says:

It is incomprehensible only from the point of view of a common sense or that of an exercise traced from the empirical that, for example, thought should find within itself 
something which it cannot think something which is both unthinkable and that which must be thought. (Deleuze, 1997:192)

My suggestion is that by becoming a trope in La Garganta de Albers, Las Muelas de Gaudi the facade is encountered in its essence. This essence is an unconscious Idea that cannot be experienced as such; it is not a subjective act of representation but an involuntary eruption. This is not a universal essence but in principle it is specific to the encounter with the material object and, in a moment of temporal synthesis, there is the creation of an unconscious Idea. It is as if the pure and empty form of the façade is a schematisation of a moment of incomprehensibility in which there is no content, no knowledge, and which marks a radical moment of discontinuity in the subject. This moment of discontinuity is significant if we want to understand a work to have a commitment to its outsides. It is not simply to acknowledge that the work cannot 'cause' a response (and therefore manipulate its audience or indeed allow us to measure a work's efficacy at engaging with social issues) but this discontinuity is the moment when we are forced to think; not to represent to ourselves what we already know but to face the real.

The virtual is opposed not to the real but to the actual. The virtual is fully real in so far as it is virtual. Exactly what Proust said of states of resonance must be said of the virtual: 'Real without being actual, ideal without being abstract'; and symbolic without being fictional. (Deleuze, 1997:28] 


\section{References - The Façade and the Picture Plane}

Bains, P. (2001) 'Umwelten' in Semiotica 134-1/4 2001, pp137-167.

Benjamin, W. Iluminations (1992), London, Fontana.

Bois, Y-A (1990) Painting as Model, London, The MIT Press.

de Beistegui, M, (2013) Proust as Philosopher: The Art of Metaphor, Abingdon, Routledge.

Damisch, H. (2011) 'The Theoretical Eye' in Journal of Art Historiography, No. 5, pp1-11.

Deleuze, G. (2000) Proust and Signs, London, Athlone.

Deleuze, G. (1997) Difference and Repetition, London, Athlone.

Deleuze, G. and Guattari, F. (1994) What is Philosophy? London, Verso. 
Faulkner, K. (2005) 'Deleuze and Essence', in Pli: The Warwick Journal of Philosophy, Volume 16 pp129-148.

Goddard, M. (2005) 'The Surface, the Fold, and the Subversion of Form: Towards a Deleuzian Aesthetic of Sobriety', in Pli: The Warwick Journal of Philosophy, Volume 16, pp1-26.

Jakobson, J. (1987) Language in Literature, Harvard, Harvard University Press. pp 95-114

Maturana, H. and Varela, F. (1980) Autopoiesis and Cognition: The Realization of the Living, Dortrecht, Reidel.

Simondon, G. (1992) "The Genesis of the Individual," in Jonathan Crary \& Sanford Kwinter (eds.), Incorporations, New York: Zone Books, pp. 297-319.

Smith, D. (2013) 'The Conditions of the New', in Essays on Deleuze, Edinburgh: Edinburgh University Press, pp. 235-255.

Scott, D. (2014) Gilbert Simondon's Psychic and Collective Individuation, Edinburgh: Edinburgh University Press. 
Vidler, A. (2005) 'Damisch avec Architecture' in Oxford Art Journal Vol. 28, No.2, pp203-211.

Williams, J. (2011) Gilles Deleuze's Philosophy of Time, Edinburgh, Edinburgh University Press.

Catherine Ferguson

School of Fine Art, History of Art and Cultural Studies

University of Leeds

Leeds LS2 9JT

c.m.ferguson@leeds.ac.uk

Author's biography

Catherine Ferguson is an artist and writer based in London. She completed a Fine Art PhD in 2007 titled Painting, Deleuze and the Art of "Surface Effects" and is a lecturer in Fine Art at University of Leeds and a visiting tutor at Chelsea College of Art. 